\title{
Ankylosing spondylitis with mycetoma case treated with oral itraconazole
}

Taha Bekci · Recep Kesli • Emin Maden · Orhan Ozbek

Published online: 16 September 2009

(C) Springer-Verlag 2009

\section{Erratum to: Rheumatol Int}

\section{DOI 10.1007/s00296-009-1088-z}

Unfortunately the second author's name had been misspelled. The correct name is Recep Kesli.

The online version of the original article can be found under doi: 10.1007/s00296-009-1088-z.

T. Bekci $(\bowtie)$

Department of Pulmonary Medicine,

Konya Education and Research Hospital,

Meram Yeniyol, Meram, 42100 Konya, Turkey

e-mail: tahabekci@yahoo.com

R. Kesli

Department of Microbiology,

Konya Education and Research Hospital, Konya, Turkey

e-mail: recepkesli@yahoo.com

E. Maden

Department of Pulmonary Medicine,

Meram Medical Faculty, Selcuk University, Konya, Turkey

e-mail: eminmaden@yahoo.com

O. Ozbek

Department of Radiology, Meram Medical Faculty,

Selcuk University, Konya, Turkey

e-mail: orhan.ozbek@gmail.com 